\title{
ENVIRONMENTAL LAW OR ENVIRONMENTAL PROTECTION LAW? A COMPARATIVE LEGAL ANALYSIS
}

\begin{abstract}
The problem of environmental law and environmental protection law is not only a terminology issue. Using either of the two terms, the lawmaker reveals its vision of regulating environmental issues in the system of law. In environmental protection law the protective nature of a legal norm is emphasized, and at the same time the control and supervisory powers of public administration authorities are increased. In the case of environmental protection law the confrontation element is in the foreground and the lawmaker immediately advocates the environment.

On the other hand, in the case of environmental law the predominant element is conciliation, that is, the reconciliation of conflicting values. The role of the authorities is not limited to control and supervision, but rather they should resolve conflicts between different values.

Although the system of Polish law traditionally uses the name "environmental protection law" in the language of law and the language of lawyers, the predominant elements are characteristic of environmental law - conciliation elements with the principle of sustainable development at the forefront. Therefore, the name of this area of normative regulations should be reviewed and environmental protection law should be renamed "environmental law".
\end{abstract}

Keywords

environmental law - environmental protection law

\footnotetext{
* Professor doctor habilitated in environmental protection law, professor of the Nicolaus Copernicus University, professor of the Kazimierz Wielki University. Head of the Chair of Environmental Protection Law of the Nicolaus Copernicus University in Torun, legal advisor.
} 
Comparative legal analysis plays a significant role in contemporary jurisprudence. Objectives defined for comparative law lead to improved knowledge and understanding of the national system of law or its component parts. They also facilitate better learning and understanding of foreign systems of law or their component parts. Finally, comparative law facilitates better learning and understanding of supranational systems of law or their component parts. Another value of comparative law is the use of the results of comparative legal analyses in forming typologies and models, classifications and systems of comparative law ${ }^{1}$.

Thus, it is difficult to overestimate values made real by comparative law and at the same time to underestimate its value for environmental protection law. The significance of comparative law in this regulatory area concerning social relationships is reinforced by the significance and determination following from European environmental law.

This study aims to analyze the terms "environmental law" and "environmental protection law" and the conceptual consequences of using the aforementioned terms.

In theoretical literature comparative law is not interpreted uniformly. A. Kozak notes that comparative law is an "idiosyncratic area of law, and at another time one of the methods of interpretation of law" 2 .

It can be noticed that approaches to comparative law vary significantly. On the one hand, comparative law is regarded as a separate discipline of law and is treated as such. On the other hand, some people recognize it exclusively as one of the methods of studying law.

One of the most outstanding legal experts studying the issues of comparative law, R. Tokarczyk, perceives it as a discipline of

\footnotetext{
1 See K. Lubiński, Przedmiot komparatystyki prawa procesowego [The Subject of Comparative Procedural Law], [in:] Proces cywilny. Nauka - kodyfikacja - praktyka. Ksiega jubileuszowa dedykowana Profesorowi Feliksowi Zedlerowi [Civil Proceedings. Science - Codification - Practice. A Jubilee Book Dedicated to Professor Feliks Zedler], Warszawa: Wolters Kluwer Polska 2012, p. 2.

2 A. Kozak, [in:] A. Bator (ed.), Wprowadzenie do nauk prawnych. Leksykon tematyczny [An Introduction to Jurisprudence. A Thematic Lexicon], Warszawa: LexisNexis Polska 2012, p. 25.
} 
jurisprudence ${ }^{3}$. Some views, also formulated within legal doctrine, postulate that comparative law is only a method of studying law ${ }^{4}$.

Thus, as a matter of fact, the lines of study in comparative law are determined by whether a particular author considers comparative law to be a discipline of jurisprudence or a method of studying law.

In my opinion, comparative law should be regarded taking both approaches into account.

In the first place, comparative law is a method of studying law. It is about comparing specific elements and studying them in parallel in two or more systems of law. The line of study is solely determined by the intention of the jurisprudent who can focus on details, more general structures, and finally - on the most extensive issues. Thus, the essence of a specific problem is investigated with reference to other systems of law. A jurisprudent will resort to comparative law in order to solve a sneaking problem within a specific legal system.

However, one must not forget that comparative law has developed its own theory; but this theory does not focus solely on the technical instruments for studying law, but also on other issues ${ }^{5}$. Comparative law has its own formulated goals and investigated lines of development. Finally, conscious analysis of the application of the findings in the legislative practice of a specific country forms an important part of the theory of comparative law. As a consequence, it is postulated that comparative law is a discipline of science and that it is a relatively young discipline $^{6}$. The latter view encourages the investigation of issues related to

\footnotetext{
3 R. Tokarczyk, Filozofia prawa [The Philosophy of Law], Warszawa: LexisNexis 2009, p. 41.

4 As in: J. Bardach, Metoda porównawcza w zastosowaniu do powszechnej historii państwa i prawa [Comparative Method Applied to General History of the State and Law], Czasopismo PrawnoHistoryczne [Law and History Magazine] 1962, vol. 14, no. 2, p. 32 et seq.; S. Szer, Metoda prawnoporównawcza w prawie cywilnym i rodzinnym [Comparative Legal Analysis in Civil and Family Law], Państwo i Prawo [State and Law] 1967, no. 1, p. 25; R. L. Ludwikowski, Prawo konstytucyjne porównawcze [Constitutional Comparative Law], Torun: Dom Organizatora TNOiK 2000; K. Lubiński, O rozwoju europejskiej komparatystyki prawa procesowego [On the Development of European Procedural Comparative Law], [in:] R. Tokarczyk (ed.), K. Motyka (ed.), Ze sztandarem prawa przez świat. Księga dedykowana Profesorowi Wieńczysławowi Wagnerowi von Igelgrund z okazji 85 - lecia urodzin [Around the World under the Flag of the Law. A Book Dedicated to Professor Wieńczystaw Wagner von Igelgrund on the Anniversary of His 85 th Birthday], Kraków: Zakamycze 2002, p. 201 et seq.

5 As in, for instance, M. Pavčnik, Teorija prava, Ljubljana: GV založba 2007, p. 62 et seq.

6 M. Rainer, Corso di sistemi giuridici comparati, Torino: G. Giappichelli 2004, p. 23 et seq.
} 
the names of respective disciplines, branches, divisions of law and their scope, etc. In the first place, it refers to areas of law that are relatively young and are still being shaped, and at the same time it is difficult to precisely define the scope of the normative matter they cover. Such a part of the system of law is exemplified by environmental protection law, also referred to as environmental law.

Apparently, the problem refers to such an insignificant issue as the name of the subject, discipline, division or perhaps a branch of law. However, behind the use of specific names there are solutions which are fundamental to the whole system. It could be declared that the term "environmental law" or "environmental protection law" reflects the approach of the lawmaker to the concept of regulating the legal matter regarding the environment.

Thus, comparative studies regarding the name are at the same time studies regarding the concept and vision of the lawmaker inspiring the approach to environmental issues.

In the system of Polish law the term "environmental protection law" is definitely predominant. The determinative factor is the title of the legal act that is fundamental to environmental protection law - namely the Act of 27 April 2001 - the Environmental Protection Law7

Generally, the name of this legal discipline alone does not raise any doubt and is commonly accepted. The term "environmental protection law" is used by the authors of a leading handbook in this area ${ }^{8}$. At the same time, the significant issue, that is the expected role of law in environmental protection, is analyzed. "Firstly, the norms should define the tasks of both the state (here mainly the norms of the highest level legal acts) and the state authorities and of any entities having impact on the environment. Secondly, the norms should be an independent measure to fulfil specific tasks but simultaneously they will regulate the form and method of use of other measures - technical, economic, educational, etc. Legal norms must handle both roles together - the specification of protective tasks alone

7 Dz. U. [Journal of Laws] of 2008, No. 25, item 150 as amended.

8 M. Górski (ed.), Prawo ochrony środowiska [Environmental Protection Law], Warszawa: Wolters Kluwer Polska 2009. 
without concurrent establishment of effective measures to fulfil them, is a completely missed action" 9 .

A. Lipiński uses the term "legal framework of environmental protection", although he also advocates the use of the term "environmental protection law". In turn, he emphasizes the protective nature of this group of legal norms ${ }^{10}$.

Also, J. Ciechanowicz-McLean consistently makes use of the term "environmental protection law"11.

R. Paczuski reasonably noted that "Environmental protection law is a legal term which has become rooted in legal literature, administrative practice and teaching after the EPL-Act [law on the protection and shaping of environment - note by B.R.], a breakthrough in the development and systematization of the legal framework of environmental protection in Poland, became effective"12. Further, the above-named author lists the various meanings of the term "environmental protection law". In his opinion, the crucial one is the normative meaning of the term "environmental protection law", that is, "all legal regulations in force related to environmental protection with clearly defined goals and programme assumptions, consistent with the global environmental protection policy based on UN documents"13.

The term "environmental protection law" is also used by other representatives of the doctrine ${ }^{14}$.

The term "environmental protection law" is also a subject of interest for encyclopaedic and lexicon-like works. This term is mostly analyzed in terms of its multiple aspects and variety. These considerations focus on investigating whether or not environmental protection law is

\footnotetext{
9 M. Górski, [in:] Górski (ed.), supra note 8, pp. 38-39.

10 A. Lipiński, Prawne podstawy ochrony środowiska [Legal Framework of Environmental Protection], Warszawa: Wolters Kluwer Polska 2010, b. 29.

11 J. Ciechanowicz-McLean, Prawo i polityka ochrony środowiska [Environmental Protection Law and Policy], Warszawa: Wolters Kluwer Polska 2009, p. 21 et seq.

12 R. Paczuski, Prawo ochrony środowiska [Environmental Protection Law], Bydgoszcz: Oficyna Wydawnicza Branta 2000, p. 107.

13 Ibid.

14 Cf. for instance M. Bar, J. Jendrośka, Prawo ochrony środowiska. Podręcznik [Environmental Protection Law. A Handbook], Wrocław: Centrum Prawa Ekologicznego 2005; B. Wierzbowski, B. Rakoczy, Prawo ochrony środowiska. Zagadnienia podstawowe [Environmental Protection Law. Fundamentals], Warszawa: LexisNexis Polska 2012.
} 
an independent branch of law 15 . Also, it must be noted that "environmental protection law" is also a procedural term ${ }^{16}$.

The presentation of these fundamental views alone enables the formulation of general conclusions. Without any doubt, the doctrine of Polish law, following the title of the fundamental legal act, uniformly adopted the name "environmental protection law" instead of "environmental law".

Moreover, the view that it is to some extent separated and has characteristic features is predominant. Also, the multiplicity of meanings of the term "environmental protection law" is generally acceptable.

Meanwhile, "environmental law" is commonly used by various other systems of law. Thus, the term "protection: is removed, which is not only of technical, cultural and traditionalist significance, but also lays the foundations for the concept underlying this group of legal norms.

The Italian legal doctrine commonly makes use of the term "environmental law" (Italian: il diritto dell'ambiente or il diritto ambientale).

The doctrine of Italian law formulates a view that environmental law deals with environmental protection issues, but at the same time the significance of the fundamental right of man to protect the conditions necessary for proper development is emphasized 17 .

The term "environmental law" is also used in a major handbook by B. Caravita. This author analyzes the characteristic features of environmental law, although the analysis is not concluded with a definition of this regulatory area ${ }^{18}$.

S. Maglia indicates that the term "environmental law" he uses should be defined with reference to the term "environment" 19 .

\footnotetext{
15 Cf. B. Rakoczy, [in:] J. Ciechanowicz-McLean, Leksykon ochrony środowiska [The Lexicon of Environmental Protection], Warszawa: C. H. Beck 2009, p. 278 et seq.; A. Haładyj, [in:] M. Domagała, A. Haładyj, S. Wrzosek (eds), Encyklopedia prawa administracyjnego [The Encyclopaedia of Administrative Law], Warszawa: C. H. Beck 2010, pp. 272-273.

16 Vide B. Rakoczy, Le droit procédural de l'environnement, [in:] J. Niczyporuk (ed.), Les problémes théoriques de la science administrative, Bruxelles, Paris: Académie Polonaise des Sciences 2012, pp. 291-298.

17 Compendio di Diritto dell'Ambiente, Napoli: Simone 2006, p. 10.

18 B. Caravita, Diritto dell'ambiente, Milano: Mulino 2009.

19 S. Maglia, Diritto ambientale Alla luce del. D. Lgs 152/2006 e successive modificazioni, Milano: Wolters Kluver Italia 2009, p. XVII.
} 
One of the fuller definitions of "environmental law" is given by F. Marchello, M. Perrini, and S. Serafini. They perceive environmental law as a specialized branch of public law dealing with the study of the sources of Italian, international and European law in the context of environmental protection. However, they also emphasize that environmental law deals with using environmental resources ${ }^{20}$.

It must also be noted that the Italian literature uses the term "il diritto ambientale" 21 .

In turn, German literature makes common use of the term "Umweltrecht", which should be translated as "environmental law". Thus, the terminology used regarding the specific area of legal regulations tends to be consistent with its usage in Italian law. However, it must be noted that the term "Umweltschutzrecht" (environmental protection law) is also used, although definitely less frequently ${ }^{22}$.

"Umweltrecht" is defined similarly to the Italian "il diritto dell'ambiente". Numerous definitions pay attention to the relationship between environmental protection and sustainable development ${ }^{23}$ or conceptualize environmental protection primarily in terms of international law and European law24. However, it is often recognized that the environment cannot be seen solely in terms of environmental protection, but also in terms of its economic significance and utilisation ${ }^{25}$. Individual rights are also emphasized in the environmental context ${ }^{26}$.

The Czech legislator and doctrine make use of interesting terminology. In Czech law the analyzed environmental area is referred to as the law of the living environment. Attention is attracted to the protective nature of the legal norm but not only with reference to the environment, but also

20 F. Marchello, M. Perrini, S. Serafini, Diritto dell'Ambiente, Napoli: Edizioni giuridiche Simone 2007, pp. 10-11.

21 As in for instance E. Mariotti, M. Iannantuoni, Il nuovo diritto ambientale, Santarcangelo di Romagna (Rimini): Maggioli 2011.

22 As in for instance M. Kloepfer, Umweltschutzrecht, München: C. H. Beck 2008.

23 H.-J. Koch, Umweltrecht, München: Heymanns 2007, p. 1.

24 As in J.-D. Oberrath, O. Hahn, T. Schomerus, Kompendium Umweltrecht. Leitfaden für Studium und Praxis, Stuttgart, München, Hannover, Berlin, Weimar, Dresden: Boorberg 2003, p. 28.

25 R. Schmidt, W. Kahl, Umweltrecht, München: C. H. Beck 2007, p. 3 et seq.

26 M. Buck, R. Verheyen, [in:] H.-J. Koch, Umweltrecht, Hamburg: Carl Heymanns 2002, p. 3. 
with reference to man ${ }^{27}$. M. Pekárek points to the distinctness of both terms - "environment" and "living", but at the same time analyzes both terms together, recognizing their normative and non-normative relationship ${ }^{28}$.

Collating the names "environmental law" and "environmental protection law", which - as mentioned above - occur in different systems of law, and confronting them with each other is not only a comparative discussion concerning the name. It could be reasonably argued that the dispute refers only to the name of the same area of legal regulation, that is, the attitude of the state and of individuals to the environment, which is evidenced by terminology adopted in Czech law.

The focus of the legislator's attention in the environmental law/environmental protection law is the environment as the commonwealth. The above-formulated assumption, limited to emphasizing that the environment is a subject of protection, would be fully justified. Meanwhile, the usage of the name is only of secondary importance. The designation of this area of legal regulations is a consequence of the legislator's attitude to the environmental matter. In point of fact, both names differ in the use of the term "protection".

The above-presented definitions of "environmental protection law", characteristic of the Polish doctrine, most of all emphasize the protective nature of legal norms. The Polish legislator, using the term "environmental protection law" indicates that its fundamental intention and purpose is to create protective norms. It remains at the level of considerations regarding the admissibility of intruding on the environment and having impact on such environment. Legal norms in this approach are mostly designed as barriers preventing or restricting access to environmental resources. A legal norm should, a priori, protect the environment, and speaking more closely, its respective elements against impact.

In this case the preventive and conservational function of law is reinforced. The legal norm should cause the environment to be maintained in a non-deteriorated condition and, preferably, it should prevent any impact on the environment.

27 M. Damohorský (ed.), Právo životního prostředí, Praha: C. H. Beck 2007, p. 28.

28 M. Pekárek (ed.), Právo životního prostředí, Brno: Masarykova univerzita 2009, p. 11. 
The emphasis is distributed in a slightly different manner if the legislator uses the term "environmental law". Elimination of the term "protection" from terminology used by the language of law or the language of lawyers is not just a simple legislative or doctrinal operation. Likewise in the previous case, also in this situation, the term "environmental law" defines the attitude of the legislator to the environment. Due to the conscious resignation from using the term "protection" the legal norm will not perform a protective function only, but it will also have other functions to be described hereinafter.

In environmental law the legislator does not solely give thought to whether people should have an impact on the environment and obtain its resources, but also deliberates how people should impact the environment and obtain its resources ${ }^{29}$. Thus, the emphasis is shifted from "whether" to "how". Only when the legislator considers that living in the contemporary world, managing business, organizing society, running the economy, and even political activity are impossible without exerting an impact on the environment and obtaining its resources, could emphasis on the protective nature of legal norms be given up.

Another step in this concept should be the creating of legal norms and instruments focusing on the rational impact on the environment and rational obtaining of environmental resources. Further, the legislator proposes that environmental resources should be replaced by other elements, which is particularly noticeable in relation to renewable energy. The rule of sustainable development is excellently inscribed in such concepts of environmental law. Leaving deep theoretical considerations aside (as they are not the subject of this article) it must be noted that the essence of sustainable development is the avoidance of confrontation for the sake of conciliation in the concept of environmental law. The main objective of the addressee of the legal norm is to identify a potential controversy between the various values protected by law, the environment being one of such values.

Having identified the controversy, the addressee of the legal norm should resolve it so that both conflicting values are accomplished to the fullest possible extent. Only if the conflicting values cannot be objectively

29 Cf. M. Stallworthy, Understanding Environmental Law, London: Sweet \& Maxwell 2008, p. 4. 
reconciled, must the addressee of the legal norm resort to confrontation. Nevertheless, before the environment is confronted with other values in the concept of environmental law, conciliation activities must be undertaken. Only if such measures fail, can the addressee of the legal norm choose one of the conflicting values, but at the same time they are obliged to explain to other addressees of the legal norm the motives behind their choice.

Meanwhile, in the concept of environmental protection law the confrontation element is in the foreground, while the conciliation element is either in the background or disappears completely. Choosing the concept of environmental protection law the lawmaker is aware of the conflict existing between the environment and other values, but this conflict is resolved by giving normative support to the environment and indicating that the legal norm is supposed to protect it.

Another consequence of choosing a specific concept is a different distribution of emphasis regarding the instruments of legal regulations. In the case of the concept of environmental protection law, as mentioned above, the potential conflict is resolved by means of a legal norm. Consequently, the public administration authority is not appointed primarily in order to resolve this conflict by the operation of law, but to carry out control and supervision activities regarding compliance with normative conditions.

On the other hand, in the concept of environmental law, the lawmaker determines the conditions governing the use of the environment and environmental impact, but leaves the competence to resolve potential conflicts in specific cases involving specific elements of the environment, specific entities making use of the environment in specific social, economic, political and environmental conditions, to executive authorities.

The aforementioned considerations of comparative law regarding the name of the specified normative area, as a matter of fact referring to a specific vision and place of the environment in the system of law, should stimulate the Polish legislator to reflect on which model it supports.

Without any doubt, Polish environmental protection law is constructed in a way characteristic of environmental law. The core of the Polish environmental protection law is the principle of sustainable development 
expressed in Article 5 of the Constitution of the Republic of Poland of 2 April 199730.

The essence of sustainable development was perfectly explained by the Constitutional Tribunal in its decree of 6 June 2006, application no. K 23/05. It indicated that:

The provisions appealed against are thus consistent with Article 5 and with Article $74 \S 1$ and 2 of the Constitution. Public authorities are first of all required to "pursue a policy ensuring ecological security to the present and future generations" (Article $74 \S 1$ ). This phrase is typical for the determination of the tasks (policy) of the state, but it does not directly give rise to any rights of an individual. The term "ecological security" must be understood as bringing the environment to a condition allowing the safe staying in such an environment and using such an environment to enable human development. Environmental protection is one of the elements of "ecological security", but the tasks of public authorities are wider they also cover activities improving the current condition of the environment and programming its further development. The fundamental method to accomplish this objective is - pursuant to Article 5 of the Constitution - to be guided by the principle of sustainable development, which makes reference to international agreements, in particular those made at the conference in Rio de Janeiro in 1992 (cf. J. Boć (ed.), Konstytucje Rzeczypospolitej oraz komentarz do Konstytucji RP $z 1997$ r. [Constitutions of the Republic of Poland and the commentary to the Constitution of the Republic of Poland from 1997], Wrocław: Kolonia Limited 1998, p. 24 et seq.). The principles of sustainable development comprise not only environmental protection or land management, but also due care for social and civilisation development related to the necessity of building the appropriate infrastructure required for - taking into account the needs of civilisation - the life of man and respective communities. Thus, the idea of sustainable development incorporates a need to take various constitutional values into account and balance them properly.

30 Dz. U. [Journal of Laws] No. 78, item 483 as amended. 
Polish environmental protection law no longer focuses on the protective elements, but on elements ensuring proper use of the environment. It does not answer the question whether it makes use of the environment and environmental resources, but attempts to answer the question of how to make use of the environment and environmental resources or, in other words, to what extent people can exert an impact on the environment and make use of environmental resources.

As a consequence, one should consider whether the name of the analysed normative area - environmental protection law - is still adequate to the substance of the regulation. Of course, one could reply that the choice of this name is traditional since from the very beginning this area of normative matter was referred to as "environmental protection law". Nevertheless, perhaps it is time to give a new, more adequate name to this area. Indeed, this is the most dynamically developing area of legal regulations.

To sum up, the problem of environmental law and environmental protection law is not only a terminology issue. Using either of the two terms the lawmaker reveals its vision of regulating environmental issues in the system of law. In environmental protection law the protective nature of a legal norm is emphasized, and at the same time the control and supervisory powers of public administration authorities are increased. In the case of environmental protection law the confrontation element is in the foreground and the lawmaker immediately advocates the environment.

On the other hand, in the case of environmental law the predominant element is conciliation, that is, the reconciliation of conflicting values. The role of the authorities is not limited to control and supervision, but rather to resolving conflicts between different values.

Although the system of Polish law traditionally uses the name "environmental protection law" in the language of law and the language of lawyers, the predominant elements are characteristic of environmental law - conciliation elements with the principle of sustainable development in the forefront. Therefore, the name of this area of normative regulations should be reviewed and environmental protection law should be renamed as environmental law. 
